\title{
The Martinsburg Formation
}

\section{(Middle and Upper Ordovician)}

in the Delaware Valley

Pennsylvania-New Jersey

By AVERY ALA DRAKE, JR., and JACK B. EPSTEIN

CONTRIBUTIONS TO STRATIGRAPHY

G EO LO G I A L S URVEY B U L L E T I N $1244-$ H

Prepared in cooperation with the Pennsylvania Geological Survey

$A$ clarification of the stratigraphy of clastic rocks of Middle and Late Ordovician age in western New Jersey

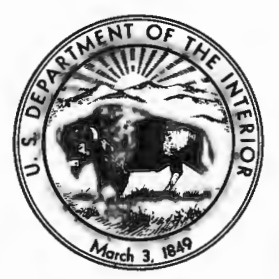
and eastern Pennsylvania 


\title{
UNITED STATES DEPARTMENT OF THE INTERIOR
}

\author{
STEWART L. UDALL, Secretary
}

\section{GEOLOGICAL SURVEY}

\author{
William T. Pecora, Director
}

U.S. GOVERNMENT PRINTING OFFICE

WASHINGTON : 1967

For sale by the Superintendent of Documents, U.S. Government Printing Office Washington, D.C. 20402 - Price 15 cents (paper cover) 


\section{CONTENTS}

$\begin{array}{lr}\text { Abstract } & \text { Page } \\ \text { Introduction } & \text { H1 } \\ \text { Martinsburg Formation } & 1 \\ \quad \text { Structural relations } & 3 \\ \text { Bushkill Member } & 6 \\ \quad \text { Ramseyburg Member } & 6 \\ \text { Pen Argyl Member } & 9 \\ \text { Summary - } & \\ \text { References cited }\end{array}$

\section{ILLUSTRATIONS}

Figure 1. Chart showing interpretations of Martinsburg stratigraphy by previous workers and by authors of this report

2. Geologic sketch map showing distribution of the Martinsburg Formation

3-6. Photographs showing:

3. Typical outerop of ribbon slate in the Bushkill Member

4. Typical exposure of Ramseyburg Member at the type locality

5. Outcrop of Ramseyburg Member showing refracted cleavage, cross-stratification, and graded bedding --

6. Typical exposure of Pen Argyl Member 



\title{
CONTRIBUTIONS TO STRATIGRAPHY
}

\section{THE MARTINSBURG FORMATION (MIDDLE AND UPPER ORDOVICIAN) IN THE DELAWARE VALLEY PENNSYLVANIA-NEW JERSEY}

\author{
By Avery Ala Drake, Jr., and Jack B. Epstein.
}

\begin{abstract}
Detailed mapping of ten $7 \frac{1}{2}$-minute quadrangles in eastern Pennsylvania and western New Jersey has shown that the Martinsburg Formation of Middle and Late Ordovician age can be divided into three members: a lower thin-bedded slate, a middle graywacke-bearing unit, and an upper thick-bedded slate. These units are herein named the Bushkill, Ramseyburg, and Pen Argyl Members, respectively. The Pen Argyl Member is buried east of the Delaware River and west of Kempton, Pa., near the Schuylkill River because of unconformable overlap by the superjacent Shawangunk Conglomerate of Silurian age. Commereial slate is presently quarried only in the Pen Argyl Member and the upper part of the Ramseyburg Member.
\end{abstract}

\section{INTRODUCTION}

Pelitic and lesser psammitic rocks of Middle and Late (Ordovician age erop out along the Appalachian Valley from Tennessee to New York, where they are eovered by rocks of the Taconic sequence near the Hudson River. In recent years these rocks, which lie between the Jacksonburg Limestone of Middle Ordovician age and the Shawangunk Conglomerate of Silurian age, have been referred to collectively as the Martinsburg Shale or the Martinsburg Slate in Pennsylvania and New Jersey. The subdivision of the formation, however, has been controversial. In this report we divide the Martinsburg into three members, eall it a formation, and clarify the stratigraphy of this complex unit. This intraformation subdivision is of the utmost importanee in deciphering the magnitude and extent of the unconformity between the Martinsburg and the overlying Shawangunk Conglomerate. 
It clarifies the geometry and mechanics of folding in this region and develops a clear picture of the Taconic orogeny. In addition, this subdivision is economically important because it fixes the stratigraphic position and areal distribution of the commercial slate in the formation.

In Pennsylvania the sequence of rocks now known as the Martinsburg was called the Matinal Series by Rogers (1858) and was thought to consist of two units, a lower black slate and an upper shale. Lesley (1892), of the Second Pennsylvania Geological Survey, assigned the rocks to the Utica and Hudson River Slates, which consisted of an upper thick-bedded and lower thin-bedded series. Dale (1906) followed this terminology but recognized a distinct difference between the "hard" and "soft" slates. In a later report (Dale and others, 1914, p. 95-96), however, he recognized a lower hard thin-bedded shale and slate, a middle member of sandstone, and an upper member of soft thick-bedded shale and slate. Peck (1908), working in the Lehigh Valley, believed the sequence contained three subdivisions, the middle of which included sandstone and graywacke. Stose (1910) first used the name Martinsburg Shale in Pennsylvania. He thought the formation consisted of a lower black shale and an upper sandstone. Behre $(1927,1933)$, in his classic works on the commercial slate districts, divided the Martinsburg into a lower. "hard" slate member, a middle sandy member, and an upper "soft" slate member. Stose (1930), working into the area of this report from the southwest, restated his belief in a bipartite interpretation of the Martinsburg and felt that Behre's upper member was the lower member repeated in the north limb of a regional syncline.

Willard and Cleaves (1939) concurred with the bipartite interpretation and named their upper member the Shochary Sandstone. B. L. Miller (in Miller and others, 1939), in his report on the Martinsburg in Northampton County, Pa. (authored with Behre), accepted Behre's tripartite interpretation, but in his later Lehigh County, Pa., report (Miller and others, 1941), the two-member interpretation is presented by Willard. Willard (1943) later raised the Martinsburg to a group, consisting of his Dauphin Shale below and Willard and Cleaves' Shochary Sandstone above.

In New Jersey, the sequence of rocks was ealled the Hudson River Slate by Cook (1868, p. 135-145), who recognized both slate and sandstone but made no attempt to subdivide the formation. Weller (1901, p. 5-8) followed the same terminology. The name Martinsburg was first applied by Bayley, Salisbury, and Kümmel (1914); the Martinsburg was thought by Lewis and Kümmel (1915) to have lower slaty and upper sandy subdivisions. 
In recent years, most geologists working in the area have accepted the name Martinsburg and espoused the bipartite interpretation. Willard's (1943) concept of a Martinsburg Group was never tested by mapping and has not been adopted by other geologists. A summary of the more important interpretation is given in figure 1.

With our colleagues J. M. Aaron, D. C. Alvord, and R. E. Davis, all of the U.S. Geological Survey, we have studied the Martinsburg Formation in the course of detailed mapping of the Bangor, Belvidere, Bloomsbury, Bushkill, Kunkletown, Nazareth, Portland, Saylorsburg, Stroudsburg, and Wind Gap 71/2-minute quadrangles (fig. 2). In this area, the Martinsburg consists, without question, of three lithologic units-a lower thin-bedded claystone slate, a middle unit of interbedded graywacke and slate, and an upper thick-bedded claystone slatemuch the same as those defined by Behre (1927).

We sincerely thank our colleagues for their generous contributions of data, as well as for their stimulating discussions of the problem.

\section{MARTINSBURG FORMATION}

The Martinsburg was named for exposures near Martinsburg, W. Va. (Keith, 1894), and forms a continuous belt of outcrops along the Appalachian Valley. Complications exist between the Susquehanna and Lehigh Rivers, where Stose (1946) attributed the presence of varicolored shales and other exotic rock types to a far-traveled Hamburg klippe. This interpretation has not gained wide support, but recent work suggests that much of the rock in that area may well be allochthonous. In any case, typical Martinsburg lithologies can be traced through to the Delaware Valley and into New Jersey. Here the Martinsburg forms a wide belt of outcrops rising in rolling hills 250-300 feet above the carbonate valley to the south and lying more than 700 feet below Kittatinny and Blue Mountains to the north (fig. 2). In addition to this major belt of outcrops, outlying bodies occur along the Musconetcong Valley in New Jersey (Bayley, Salisbury, and Kümmel, 1914; Drake, 1967a).

In the Delaware Valley, the southernmost outcrops, which are the oldest parts of the Martinsburg, are composed of thin-bedded claystone slate which contains a few thin interbeds of dolomitic siltstone near the base. This unit is succeeded to the north by an interbedded sequence of claystone slate, graywacke and graywacke siltstone that underlies hills rising 200-300 feet above the slate valleys to the southeast and northwest. These rocks are overlain by a series of thick-bedded claystone slate and scattered thin beds of graywacke. The basal slate intervals of the graywacke-bearing sequence are typical of the underlying unit, and those above are like the overlying unit. Because of 


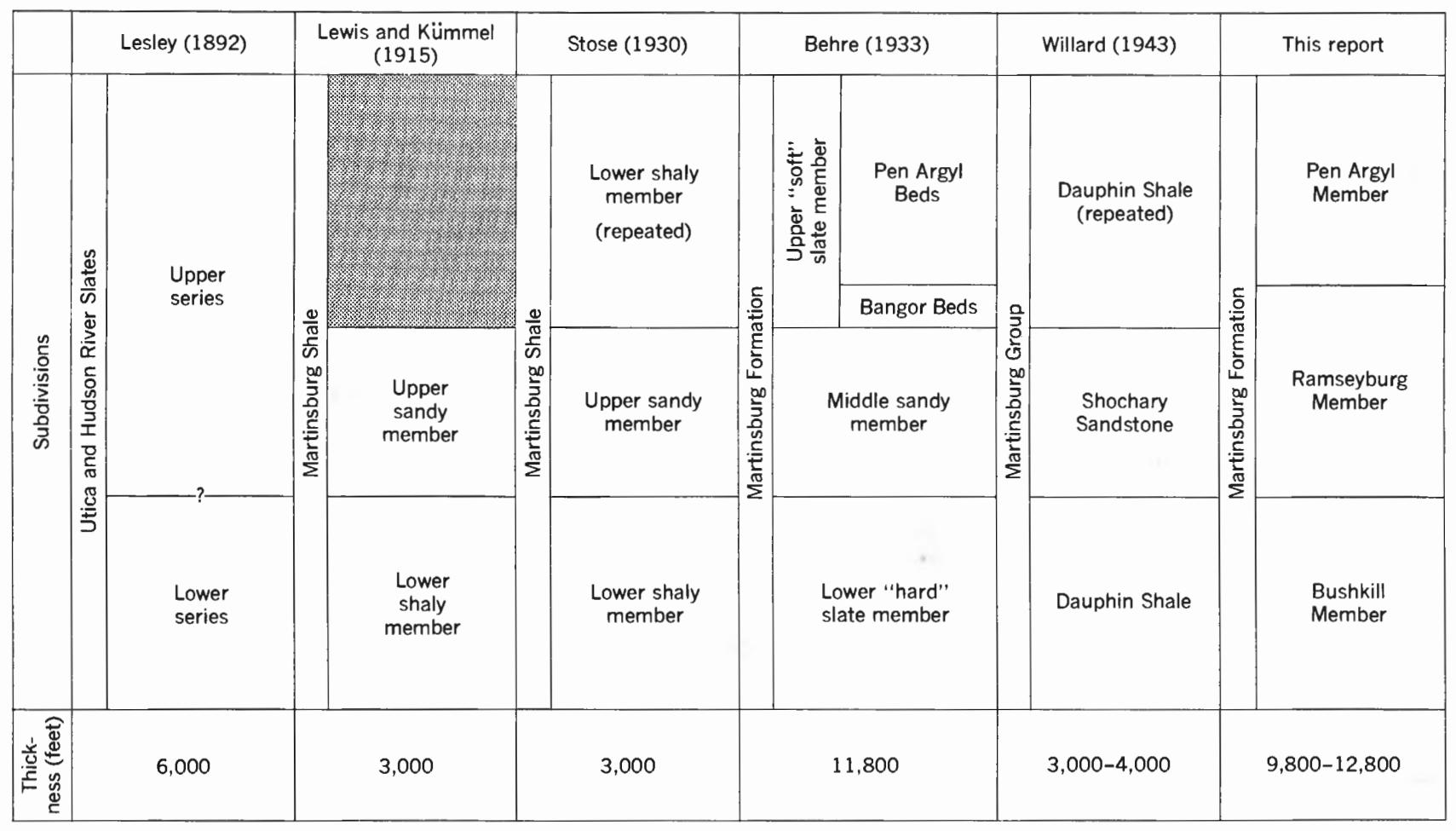

FIGURE 1.-Interpretations of Martinsburg stratigraphy by previous workers and by authors of this report. 

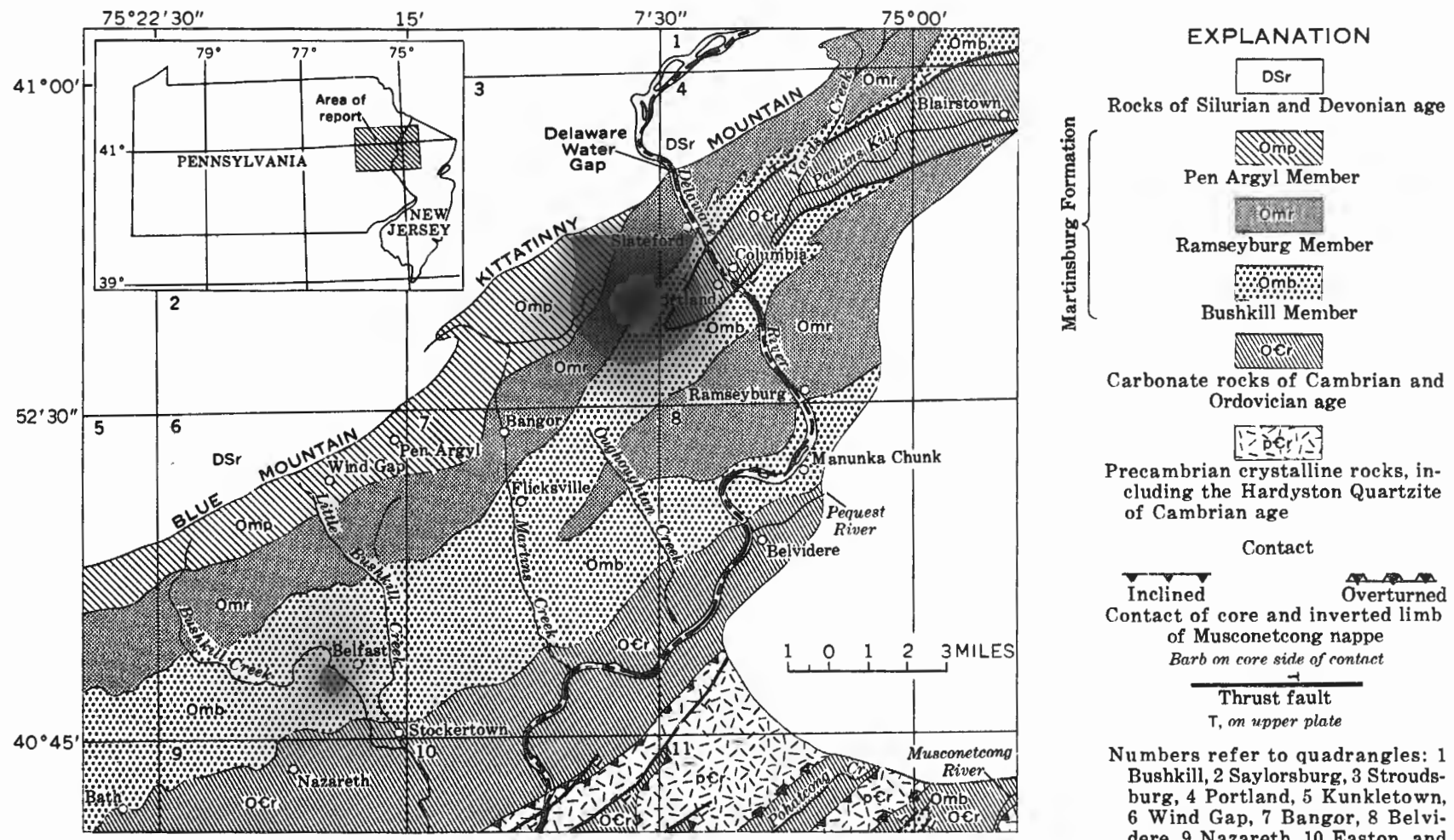

Precambrian crystalline rocks, including the Hardyston Quartzite of Cambrian age

$$
\text { Contact }
$$

Inclined

Overturned

Contact of core and inverted limb

of Musconetcong nappe Barb m core side of contact

$$
\begin{aligned}
& \text { Thrust fault } \\
& T, \text { m upper plate }
\end{aligned}
$$

Numbers refer to quadrangles: 1 Bushkill, 2 Saylorsburg, 3 Stroudsburg, 4 Portland, 5 Kunkletown, 6 Wind Gap, 7 Bangor, 8 Belvidere, 9 Nazareth, 10 Easton, and 11 Bloomsbury

Fiatre 2.-Geologic sketch map showing the distribution of the Martinsburg Formation in the Delaware Valley, Pa.-N.J. 
these different lithologies and because the Martinsburg is not a shale in this area, we herein change its lithic modifier from shale to formation.

\section{STRUCTURAL RELATIONS}

An appreciation of the regional structural geology is critical to an understanding of the Martinsburg Formation. Behre (1927, 1933) vistalized the Martinsburg as occupying a regional northwestwarddipping monocline complicated by numerous overturned, more commonly recumbent folds, some of whose axial surfaces have been rotated past the horizontal. Stose (1930) and Willard (1943) on the other hand, interpreted the Martinsburg as occupying a regional upright syncline keeled by the sandstone-bearing unit. On their sections, they also show a number of smaller upright anticlines and synclines, whose axial surfaces show no relation to the gently dipping regional penetrative, axial-plane slaty eleavage.

Current detailed mapping (Drake, McLaughlin, and Davis, 1961, 1967; Drake, 1967a, 1967b; Davis, Drake, and Epstein, 1967) has shown that the Martinsburg Formation and older rocks are involved in a highly complicated, refolded, crystalline-cored nappe de recouvrement-the Musconetcong nappe. The Martinsburg in this area lies mainly in the normal limb and imbricated brow of this nappe and has the appearance of a northwestward-dipping monocline, as visualized by Behre (1927, 1933). Stratigraphic tops are generally evident from crosssbedding and graded bedding, as well as from cleavage-bedding relâtions. Progressively younger rocks are exposed from south to north across the outcrop belt, but locally the sequence is overturned, especially in the Wind Gap-Pen Argyl area, Pennsylvania. Our mapping everywhere shows that the graywacke-bearing unit underlies the thick-bedded "soft" slate and overlies the thin-bedded "hard" slate and that the regional upright syncline postulated by Stose (1930) and Willard (1943) does not exist.

\section{BUSHKILL MEMBER}

The lower thin-bedded claystone slate unit of the Martinsburg is here named the Bushkill Member for representative outcrops along the Bushkill and Little Bushkill Creeks in the Wind Gap quadrangle, Northampton County, Pa. Excellent exposures, although of less complete sections, are also present on both sides of the Delaware River north of Belvidere, Belvidere quadrangle, Warren County, N. J., and south of Columbia, Portland quadrangle, Warren County, N. J. Good exposures are also present along Martins Creek and Oughoughton Creek, Bangor quadrangle, Northampton County, Pa. Outlying exposures are present in the Musconetcong Valley, Bloomsbury quadrangle, Hunterdon and Warren Counties, N. J., where the Bushkill 
was mapped as the lower claystone member of the Martinsburg Shale by Drake (1967a). As defined herein, the member embraces about the same sequence of rock called the lower "hard" slate member by Behre (1927).

The Bushkill Member consists of thin-bedded, dark-gray to darkmedium-gray claystone slate that weathers medium gray to very light gray to yellowish-brown. The slate contains thin to very thin interbeds of quartzose and graywacke siltstone and carbonaceous slate. Beds range in thickness from less than $1 / 8$ inch to as much as 3 or 4 inches; about 75-80 percent of the beds are probably less than half an inch thick. On Bushkill Creek, seven dolomite beds, ranging from 6 to 12 inches in thickness, lie 20-250 feet above the Martinsburg-Jacksonburg contact. Slaty cleavage is the dominant planar feature in the Bushkill

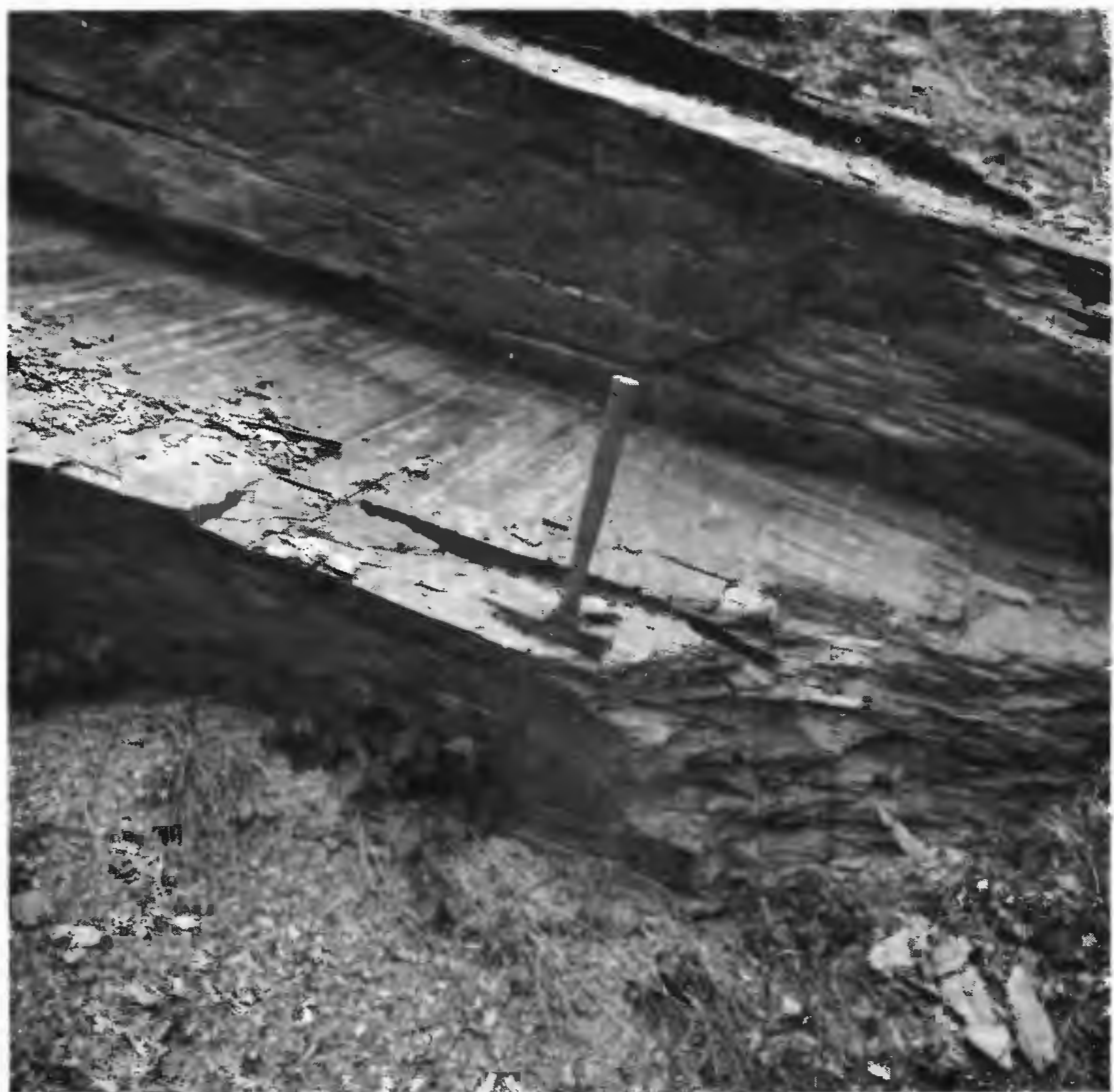

Figuke 3.-Typical outerop of ribbon slate in the Bushkill Member along unnumbered county road in Belvidere quadrangle, Northhampton County, Pa., about 1.4 miles S. $63^{\circ}$ W. from Manunka Chunk, N. J. Bédding dips gently northwest, cleavage dips gently southeast, intersection plunges $10^{\circ}$ toward the viewer. 
Member, although bedding, usually seen as color and composition bands on cleavage surfaces, is readily apparent at most places. Many of the color bands are formed by siltstone, claystone, and carbonaceous claystone that occur in cycles. Such rock has been called ribbon slate and is characteristic of this member (fig. 3).

Mineralogically, the slate consists largely of quartz and lesser amounts of sericite and chlorite. Minor amounts of calcite are present in the lower part of the member, and some beds of siltstone and claystone will effervesce very weakly in dilute hydrochloric acid. Most of the mineral grains are of clay size, although as much as 25 percent of the quartz is silt size.

The strong slaty cleavage is well marked by a strong directional orientation of the micaceous minerals. In the area north of Belvidere, N. J., and south of Portland, Pa., the slaty cleavage has been folded, and a conspicuous slip cleavage has formed. Slip cleavage is also locally conspicuous in the area to the west. Locally, sericite and chlorite are recrystallized parallel to this cleavage. In the outlying mass in the Musconetcong Valley, an area of extreme deformation, two slaty cleavages have formed.

The Bushkill Member is about 4,000 feet thick, an estimate based on the construction of geologic sections. This estimate is less than the 5,000 feet figured by Behre (1933, p. 139) for the lower member but is greater than the 2,250 estimated by Willard (1943, p. 1081-1082) for the same sequence of rocks. Our estimate may be high because of repetition by unrecognized folds and thrust faults.

In this area, the member is in conformable and gradational contact with the underlying cement-rock facies of the Jacksonburg Limestone. The transition is one of upward decrease in calcium carbonate content through an interval that is 3 feet thick on Bushkill Creek northwest of Stockertown, $\mathrm{Pa}$. This relation can also be seen in core samples taken across the contact elsewhere (Sherwood, 1964, p. 19-20). The contact is easily placed in mapping because Bushkill bedding surfaces become color banded upon weathering and those of the Jacksonburg do not. In addition, slate beds only rarely effervesce weakly in dilute hydrochloric acid, whereas the cement rock effervesces slowly and evenly.

The contact with the overlying Ramseyburg Member is transitional and is placed beneath the lowest prominent graywacke bed, which in most places is more than 1 foot thick.

No fossils have been found in the Bushkill Member in this area. The member is younger than the Jacksonburg Limestone, which most recently was considered to be of early or middle Trenton age (Cooper, 1956). Thus, the Bushkill Member must date from the middle or late Trenton, as it is gradational with the Jacksonburg. Its deposition 
continued until Eden time, as equivalent rocks to the west bear fossils of that age (Behre, 1933; Willard, 1943).

"Hard" slate has been quarried from the Bushkill Member in the areas near Portland, Flicksville, Belfast, and Bath, $\mathrm{Pa}$. This material is inferior to the slate taken from the overlying members and has been used almost entirely for roofing. In 1966 no quarries were active in this member.

\section{RAMSEYBURG MEMBER}

The middle graywacke-bearing member of the Martinsburg Formation is here named the Ramseyburg Member for representative outcrops along U.S. Highway 46 and the Erie Lackawanna Railroad near Ramseyburg, Portland quadrangle, Warren County, N. J. Good exposures of a fairly complete section are also present between Slateford, Pa., and the Delaware Water Gap in the Portland quadrangle and along the Bushkill and Little Bushkill Creeks in the Wind Gap quadrangle, Northampton County, $\mathrm{Pa}$. As defined herein, the member includes the same sequence of rocks called the middle sandy member by Behre (1927) and in addition includes the unit he (1927, p. 105106) called the Bangor Beds. These rocks are placed in the Ramseyburg Member because they include a prominent interval of graywacke at the top which provides an easily mappable upper contact in areas where exposures are otherwise poor.

The Ramseyburg Member is a sequence of alternating beds of claystone slate and light-gray to medium-gray, light-brown- to yellowishbrown-weathering, thin- to thick-bedded graywacke and graywacke siltstone. The slate in the lower cycles is identical with that of the underlying Bushkill Member in the lower 200 feet. Higher in the unit, the slate becomes progressively thicker bedded and terminates in slate "runs" like those of the overlying Pen Argyl Member, although thinbedded ribbon slate is common throughout. Graywacke constitutes an estimated $20-30$ percent of the unit.

The graywacke occurs in beds that range from less than 1 inch to more than 4 feet in thickness and average about 1 foot. The beds tend to be lenticular and of uneven thickness. The rock is rhythmically bedded (graywacke at the base passes up into medium-gray slate, which in turn passes into grayish-black carbonaceous slate), each bed normally representing one cycle; some cycles, however, are incomplete. At most places the beds also are cross-stratified, and convoluted bedding is common. Texturally, most of the unit is fine grained, but medium-grained sandstone and siltstone are also common. Fine conglomeratic beds have been noted locally. The areas of graywacke are characteristically littered with angular fragments several inches long. A typical exposure of the Ramseyburg Member at the type locality is shown in figure 4 . 


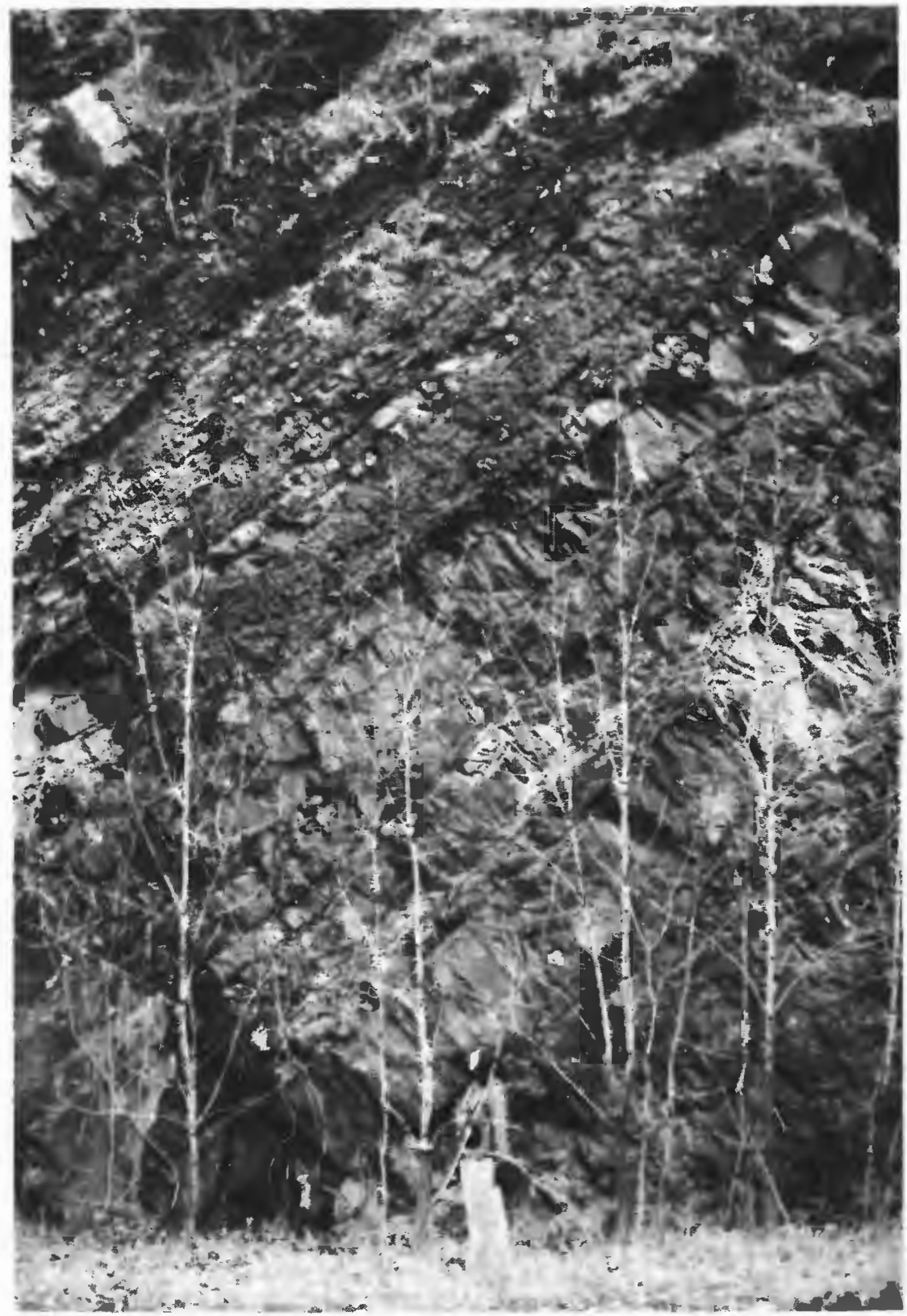

Frgure 4.-Typical exposure of Ramseyburg Member at the type locality. Bedding dips $45^{\circ} \mathrm{NW}$., slaty cleavage dips more gently northwest, and fracture cleavage dips $60^{\circ} \mathrm{SE}$. Note the range in thickness of the graywacke beds and of the sedimentary cycles. 
The average composition of the graywacke is 35 percent very fine grained detritus, 34 percent quartz, 16 percent rock fragments (mostly shale), 8 percent authigenic calcite, 5 percent feldspar (mostly microcline), and 2 percent accessory minerals. Part of the detritus has been recrystallized to recognizable muscovite and chlorite, chlorite being the more abundant. These minerals penetrate and partly to completely replace feldspar grains and are clearly metamorphic. Most grains are subangular to angular and ragged, although some are subrounded.

Claystone intervals within the member have the same well-developed, penetrative slaty cleavage so characteristic of the formation as a whole. The graywacke, in addition, displays a poor-to-good fracture cleavage that in areas of more intense deformation passes into a flow cleavage marked by alined sericite and chlorite. Characteristically, the cleavage is refracted where it passes from slate into graywacke (fig. 5).

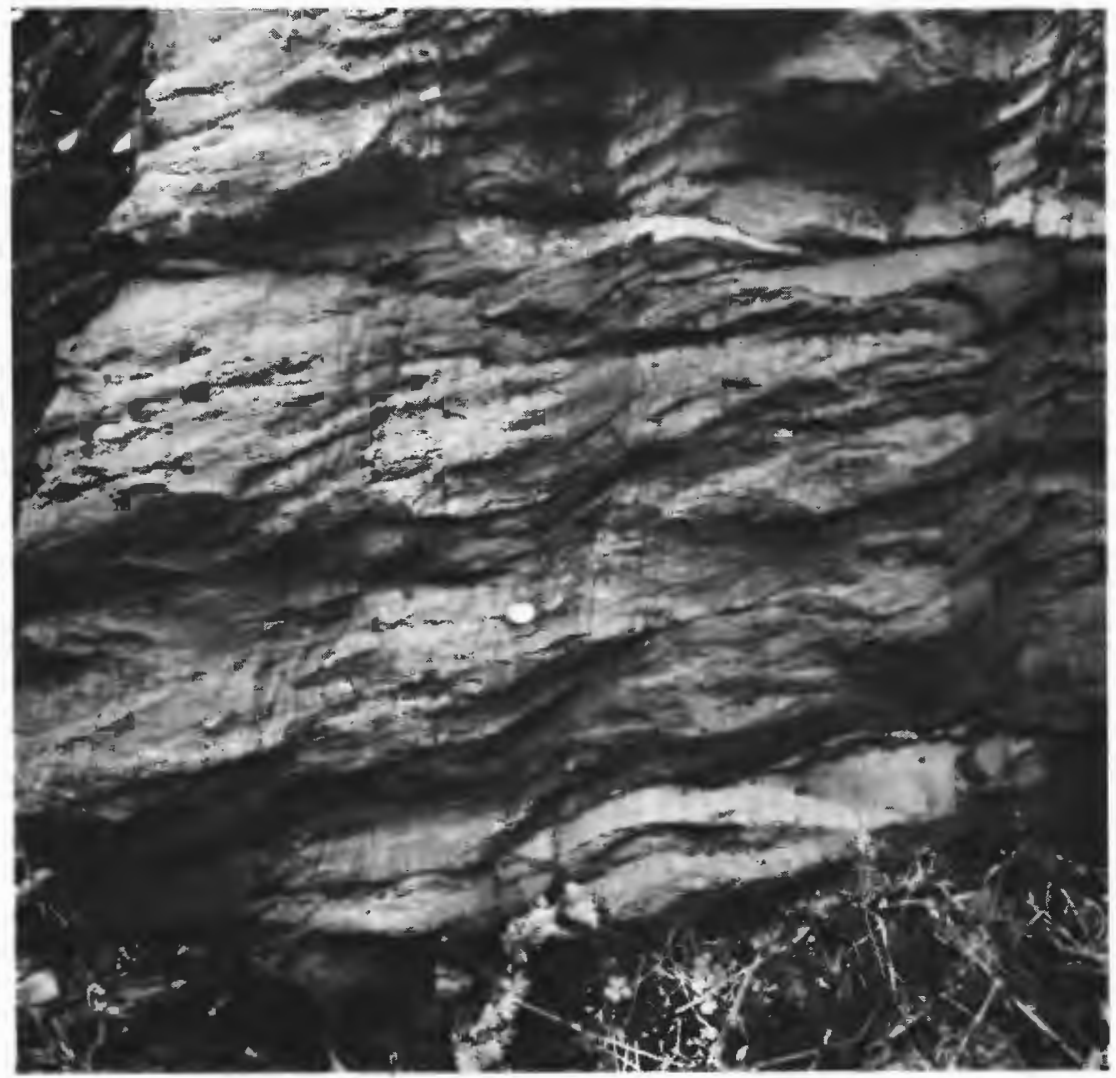

Figure 5.-Outcrop of Ramseyburg Member showing refracted cleavage, crossstratification, and graded bedding. Bedding dips steeply southeast (overturned), and cleavage dips gently southeast. Light-colored beds are graywacke, and darkcolored beds are slate. 
The Ramseyburg Member is about 2,800 feet thick, an estimate based on the construction of geologic sections. This estimate is considerably less than the 4,200 feet figured by Behre (1933, p. 140) even without the inclusion of his Bangor Beds in our unit. Graywacke beds, however, seem to be lower in the section to the southwest, and the member thickens slightly in that direction. The member is much thicker than Willard's (1943) estimate of 750 feet. Differences in reported thicknesses almost certainly reflect different regional structural interpretations.

The unit grades into the overlying Pen Argyl Member and decreases in coarse clastic content. Graywacke beds become progressively thinner and are replaced by thin beds of quartzose slate or subgraywacke siltstone in the Pen Argyl cycles. The contact is placed at the top of the highest prominent graywacke interval. East of the Delaware River, the member is unconformably overlain by the Shawangunk Conglomerate of Silurian age.

No fossils other than brachiopod debris have been found in the member in the Delaware Valley. Several collections, however, have been made from graywacke outcrops to the west (Behre, 1933; Willard, 1943). These collections suggest that the graywacke there is Maysville (Pulaski) in age. Some of the dated rock is coextensive with the Ramseyburg outcrop belt in our area, so it is possible that the Ramseyburg is Maysville in age.

Slate intervals at the top of the member have been widely exploited for commercial purposes, especially in the Bangor and Slateford areas. The material yielded is similar to that of the overlying member, although the beds tend to be thinner and somewhat more quartzose.

PEN ARGYL MEMBER

The upper thick-bedded elaystone slate unit of the Martinsburg Formation is here named the Pen Argyl Member for typical exposures in the slate quarries in and near Pen Argyl, Northampton County, Pa. The unit underlies a 2- to 4-mile wide belt south of Kittatinny and Blue Mountains but is rarely exposed in natural outcrop because of heavy cover by glacial drift. The unit can be seen, however, in quarries both northeast and southwest of the type locality, as well as in quarries south of Lehigh Gap, just west of the area covered in this report. As defined herein, the Pen Argyl Member includes about the same sequence of rock that was called the Pen Argyl Beds by Behre (1927).

The Pen Argyl Member consists of thick-bedded, dark-gray to grayish-black, medium-gray- to yellowish-brown-weathering, evenly bedded claystone slate rhythmically intercalated with thin beds of quartzose slate or subgraywacke and grayish-black to nearly black carbonaceous claystone slate. A typical cycle starts with quartzose 
slate or subgraywacke that is followed by thick-bedded slate and finally by carbonaceous slate. Individual members of a typical cycle are not always present. Slate beds are commonly 5 feet thick, but some beds are as much as 15 feet thick. Coarse clastic beds rarely exceed a foot in thickness, but some are as much as 3 feet thick. Figure 6 is a typical exposure of the unit.

The slate consists primarily of about equal amounts of sericite and chlorite, with lesser amount of calcite, quartz, and groundmass detritus. The lighter colored beds appear to have more chlorite than sericite. The carbonaceous beds owe their dark color to graphite and contain noticeable amounts of pyrite. They contain only minor quantities of chlorite. Most of the coarse clastic beds are subgraywacke similar to those beds of the underlying Ramseyburg Member, but a few beds are quartz-rich phases of the slate.

Slaty cleavage is extremely well developed in the unit and is marked by a strong parallel orientation of the micaceous minerals. A secondgeneration slip cleavage is locally common in the western part of the study area.

The Pen Argyl Member has a minimum thickness of 3,000 feet, an estimate based on the construction of geologic sections. It may be as much as 6,000 feet thick, however, as the area underlain by the unit is wide enough to accommodate this additional thickness, and an unknown thickness may be covered unconformably by the Shawangunk Conglomerate. Adequate structural reconstructions are difficult, if not impossible, in the critical areas because of the heavy cover of glacial deposits. Our minimum estimate of 3,000 feet is somewhat higher than that figured by Behre (1933) for Northampton and eastern Lehigh Counties, although he estimated a thickness of 4,415 feet for the sections along the Little Bushkill Creek.

The Pen Argyl Member is unconformably overlain by the Shawangunk Conglomerate of Silurian age. This unconformity is well shown by regional stratigraphic relations, by the difference in strike between the Shawangunk and Martinsburg in the Delaware Water Gap area (fig. 2), and regionally by two distinct topographic trends that can be seen on both topographic maps and aerial photographs, particularly high-altitude aerial photographs. This unconformable contact is probably also a décollement zone above which the overlying beds folded semi-independently of rocks in the Martinsburg. Structures in the Martinsburg believed to be of Taconic age have different tectonic styles than those formed in the overlying strata during post-Taconic deformation (Drake, Davis, and Alvord, 1960). Therefore, some of the discordance in strike at the contact may be a result of interformational slippage. The Pen Argyl Member disappears along the unconformity just west of the Delaware River (fig. 2), and no exposures 


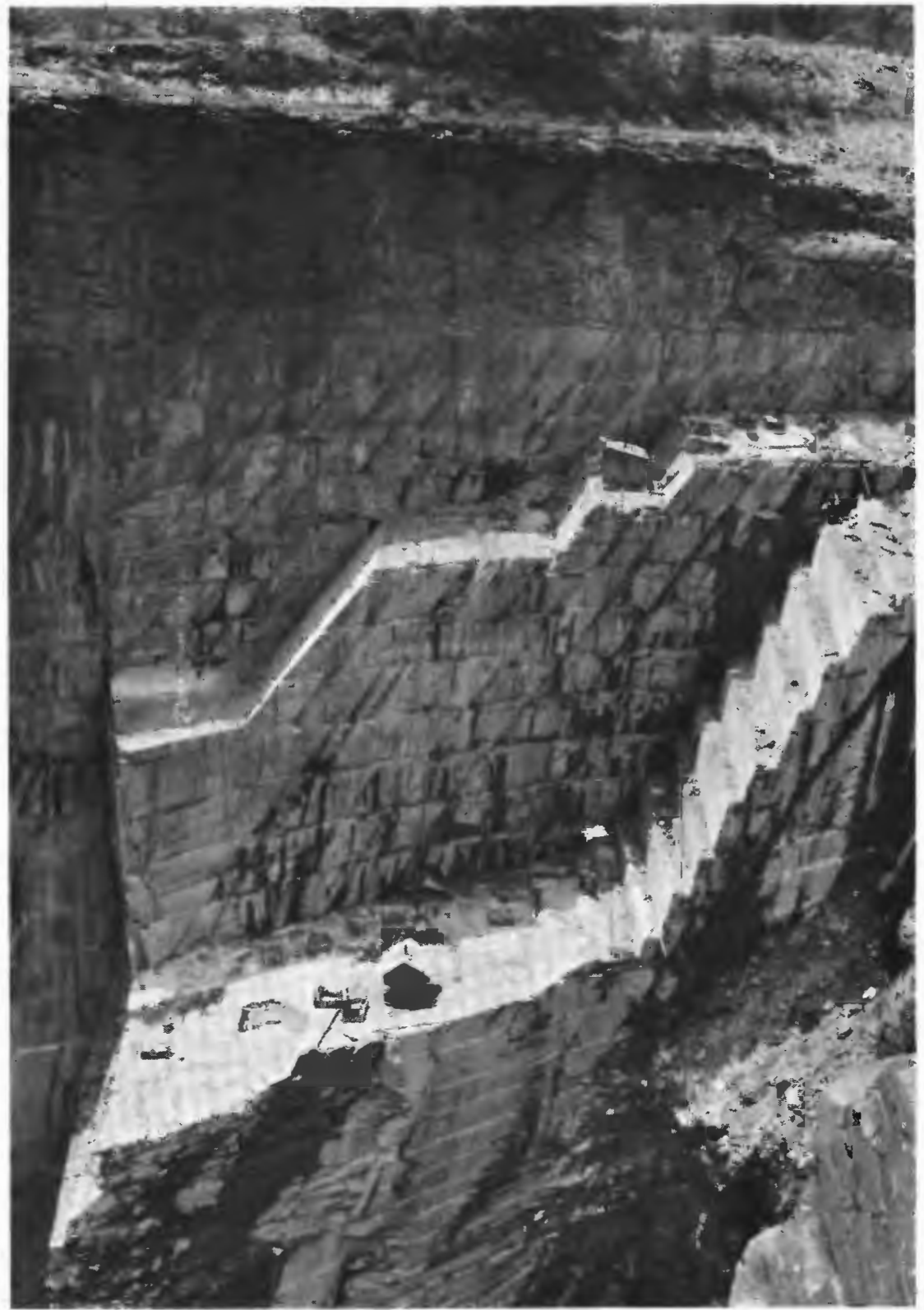

Figure 6.-Typical exposure of the Pen Argyl Member in the southwest wall of the Albion Vein Slate Co. quarry, Pen Argyl, Pa. Beds exposed are as much as 8 feet thick and lie in the inverted limb of a recumbent syncline, the axis of which lies about 400 feet below the surface. Bedding dips $45^{\circ} \mathrm{SE}$. (left) at the surface and is almost vertical at the bottom of the photograph. Cleavage dips about $10^{\circ} \mathrm{SE}$., almost parallel to the axial surface of the fold. 
are known in those parts of New Jersey that we have visited. Behre $(1927,1933)$ long ago reported that the upper part of the Martinsburg is likewise unconformably overlapped by Silurian rocks west of Kempton, Pa. We have not carried our detailed mapping that far west, but topographic trends and reconnaissance support Behre's interpretations. In addition, G. H. Wood, Jr. (oral commun., 1966), reports that pelitic rocks, similar to those in the Bushkill Member, are in contact with rocks of Silurian age at the Schuylkill Gap. This information suggests that even the graywacke-bearing Ramseyburg Member is partly covered in that area.

No fossils have been found in the Pen Argyl Member, so there is no direct evidence of its age. If the Ramseyburg Member is Maysville in age, the Pen Argyl is post-Maysville and pre-Silurian in age.

The Pen Argyl Member has yielded vast quantities of slate that has been used for a wide variety of commercial purposes. The exceptionally thick beds in the unit are especially suited for use as blackboards, billiard-table tops, and other such products.

\section{SUMMARY}

Detailed mapping in the Delaware Valley of Pennsylvania and New Jersey has shown that the Martinsburg Formation is about 9,800 12,800 feet thick and can be divided into three members: a lower thin-bedded claystone slate, a middle graywacke-bearing slate, and an upper thick-bedded claystone slate, herein named the Bushkill, Ramseyburg, and Pen Argyl Members, respectively. This subdivision is contrary to the two-fold interpretation as originally defined by Stose (1930) but is approximately the same as that of Behre (1927).

\section{REFERENCES CITED}

Bayley, W. S., Salisbury, R. D., and Kümmel, H. B., 1914, Raritan, N.J.: U.S. Geol. Survey Geol. Atlas, Folio 191.

Behre, C. H., Jr., 1927, Slate in Northampton County, Pa.: Pennsylvania Geol. Survey, 4th ser., Bull. M9, 308 p.

1933, Slate in Pennsylvania: Pennsylvania Geol. Survey, 4th ser., Bull. M16, $400 \mathrm{p}$.

Cook, G. H., 1868, Geology of New Jersey: Newark, New Jersey Geol. Survey, $899 \mathrm{p}$.

Cooper, G. A., 1956, Chazyan and related brachiopods: Smithsonian Misc. Colln., v. 127, pt. 1, p. 1-1024.

Dale, T. N., 1906, Slate deposits and slate industry of the United States: U.S. Geol. Survey Bull. 275, $154 \mathrm{p}$.

Dale, T. N., and others, 1914, Slate in the United States: U.S. Geol. Surrey Bull. $586,220 \mathrm{p}$.

Davis, R. E., Drake, A. A., Jr., and Epstein, J. B., 1967, Geology of the Bangor quadrangle, Pennsylvania-New Jersey: U.S. Geol. Survey Geol. Quad. Map GQ-665 (in press). 
Drake, A. A., Jr., 1967a, Geology of the Bloomsbury quadrangle, New Jersey: U.S. Geol. Survey Geol. Quad. Map GQ-595 (in press).

1967b, Geology of the Easton quadrangle, New Jersey-Pennsylvania: U.S. Geol. Survey Geol. Quad. Map GQ-594 (in press) .

Drake, A. A., Jr., Davis, R. E., and Alvord, D. C., 1960, Taconic and post-Taconic folds in eastern Pennsylvania and western New Jersey: U.S. Geol. Survey Prof. Paper 400-B, p. B180-B181.

Drake, A. A., Jr., McLaughlin, D. B., and Davis, R. E., 1961, Geology of the Frenchtown quadrangle, New Jersey-Pennsylvania: U.S. Geol. Survey Geol. Quad. Map GQ-133.

—_ 1967, Geology of the Riegelsville quadrangle, Pennsylvania-New Jersey: U.S. Geol. Survey Geol. Quad. Map GQ-593 (in press).

Keith, Arthur, 1894, Harpers Ferry, Va.-W. Va.-Md.: U.S. Geol, Survey Geol. Atlas, Folio 10.

Lesley, J. P., 1892, A summary description of the geology of Pennsylvania: Pennsylvania Geol. Survey, 2d Final Rept., 3v.

Lewis, J. V., and Kümmel, H. B., 1915, The geology of New Jersey: New Jersey Geol. Survey Bull. 14, 146 p.

Miller, B. L., and others, 1939, Northampton County, Pennsylvania: Pennsylvania Geol. Survey, 4th ser., Bull. C48, 496 p.

- 1941, Lehigh County, Pennsylvania: Pennsylvania Geol. Survey, 4th ser., Bull. C39, 492 p.

Peck, F. B., 1908, Geology of the cement belt in Lehigh and Northampton Counties, Pa.: Econ. Geology, v. 3, p. 37-76.

Rogers, H. D., 1858, The geology of Pennsylvania, a government survey: Philadelphia, $2 \mathrm{v}$.

Sherwood, W. C., 1964, Structure of the Jacksonburg Formation in Northampton and Lehigh Counties, Pa.: Pennsylvania Geol. Survey, General Geol. Rept. G45, $64 \mathrm{p}$.

Stose, G. W., 1910, Mercersburg-Chambersburg, Pa.: U.S. Geol. Survey Geol. Atlas, Folio 170.

Stose, G. W., 1930, Unconformity at the base of the Silurian in southeastern Pennsylvania: Geol. Soc. America Bull., v. 41, no. 4, p. 629-658.

__ 1946, The Taconic sequence in Pennsylvania: Am. Jour. Sci., v. 244, no. 10 , p. 655-696.

Weller, Stuart, 1901, A preliminary report on the Paleozoic formations of the Kittatinny Valley in New Jersey: New Jersey Geol. Survey, Ann. Rept. State Geologist for 1900, p. 1-8.

Willard, Bradford, 1943, Ordovician elastic sedimentary rocks in Pennsylvania: Geol. Soc. America Bull., v. 54, no. 8, p. 1067-1121.

Willard, Bradford, and Cleaves, A. B., 1939, Ordovician-Silurian relations in Pennsylvania: Geol. Soc. America Bull., v. 50, no. 7, p. 1165-1198. 